\title{
Metaphor in Parable from the Noble Qur'an: A Corpus Based Stylistic Approach
}

\author{
Dewi Suriyani Djamdjuri \\ English Education, Faculty of Teacher Training and education, Universitas Ibn \\ Khaldun Bogor \\ Email: dewi.suriyani@uika-bogor.ac.id
}

Zuriyati

Applied Linguistic, Postgraduate Faculty Universitas Negeri Jakarta

Email: zuriyati.pbaunj@gmail.com

\author{
Siti Gomo Attas \\ Applied Linguistic, Postgraduate Faculty, Universitas Negeri Jakarta \\ Email: sitigomoattas@unj.ac.id
}

Article Accepted: November 24, 2021, Revised: December 16, 2021, Approved: 06 January, 2022

\begin{abstract}
A compelling speech figure, a parable, or a metaphor in the Qur'an seeks to explain a crucial point by sticking in the mind and helping us absorb the message and firmly lodge it in our hearts. The stylistic method utilized in this study was a corpus-based stylistic method, which entails a contextual assessment of the term or pattern in issue. The information is based on passages from the Qur'anic corpus that have been translated into English. The stylistic corpusbased approach was used to investigate four different types of metaphor. They are standard, implied, visual, and extended metaphors, as evidenced by the findings. From the result finding it shows that there are 21 verses in the metaphor that are classified as standard metaphors, accounting for $61 \%$ of the metaphor. There are 5 verses, or $13 \%$, of implied metaphor, 7 verses, or $18 \%$, of visual metaphor, and 3 verses, or $8 \%$, of extended metaphor. The metaphor that appeared the most frequently is a standard metaphor.
\end{abstract}

Keywords: Metaphor, Parable, Noble Qur,an, Corpus-Based Stylistic

\begin{abstract}
Abstrak
Sebuah figur ucapan yang menarik, sebuah perumpamaan, atau metafora dalam Al-Qur'an berusaha untuk menjelaskan poin penting dengan menempel di pikiran dan membantu kita menyerap pesan dan dengan kuat memasukkannya ke dalam hati kita. Metode stilistika yang digunakan dalam penelitian ini adalah metode stilistika berbasis korpus, yang mencakup penilaian kontekstual terhadap istilah atau pola yang diangkat. Informasi ini didasarkan pada bagian-bagian dari korpus Al-Qur'an yang telah diterjemahkan ke dalam bahasa Inggris. Pendekatan berbasis corpus gaya digunakan untuk menyelidiki empat jenis metafora yang berbeda. Mereka adalah metafora standar, tersirat, visual, dan diperluas, sebagaimana dibuktikan oleh temuan. Dari hasil temuan menunjukkan bahwa ada 21 ayat dalam metafora yang tergolong metafora standar, yaitu sebesar $61 \%$ dari metafora. Ada 5 ayat, atau 13\%, metafora tersirat, 7 ayat, atau 18\%, metafora visual, dan 3 ayat, atau $8 \%$, metafora diperluas. Metafora yang paling sering muncul adalah metafora standar.
\end{abstract}

Kata kunci: Metafora, Perumpamaan, Al-Qur'an, Stilistika Berbasis Korpus 


\section{A. Introduction}

At some times and in certain contexts of discourse, metaphorical language has a special meaning and function for the speaker. One of them is to create beauty through language. Variables underlying the senses include speakers or sources, levels of metaphors, and ambient factors (Marsin, Iskandar, \& Attas, 2019).

Qur'anic parables are remarkable in nature since they are divinely inspired and so applicable to all people, locations, and periods (Djamdjuri, The Ability of the Fourth Semester Students in Identifying the Adjectives and Adjectival Phrases from English Translation of Surah Al-Mulk, 2014). Qur'anic parables are fascinating when they are given in the appropriate context and at the proper moment. They solve problems by using the right ingredients, which allow people to cultivate positive attitudes and good behaviors. They are role models of success and perfection who inspire people to change their mindsets and boost their self-esteem (Djamdjuri, 2016). Quranic parables, being the most visible Quran indicator examples, have made various topics clear in the best way possible through explanation and simulation (Al Hilali \& Khan, 1996). Furthermore, it appears that parable frame mental imaging is one of the essential cores of human development guidance and raising procedures, according to verses implicitly linked to the role of mental imagery. This method not only helps people build their values and personalities, but it may also be the cause of events that lead to people's mental and behavioral success. (Morteza, 2016). For the growth of a person's personality, the parables in Islamic materials are fascinating. (Djamdjuri, 2020). Because parables and fairy tales are frequently used as moral metaphors, they often speak to basic facts about human behavior and experience. This usually entails the recognition of a few fundamental images or analogies. The interpretation of similarity and distinction underpins the entire intellectual process, and metaphor is a key tool for exploring similarity and distinction (Grey, 2015).

When Allah, the Most High, explains things in the Qur'an, there are a number of ayat (verses) in which Allah, the Most High, provides greater clarity and insight to humanity. This is accomplished by employing deep and meaningful parables that are easy to comprehend and ponder for the human intellect to completely comprehend the message (Morteza, 2016). Allah intended for these parables to become embedded in His Final Revelation - in which mankind would increase understanding, accept direction, and embrace the truth-until the Last Day. Throughout history, Muslim scholars have authored many books in all fields of Qur'anic study (Al Hilali \& Khan, 1996). Nothing in English literature 
describes and explains the Qur'an's invaluable parables while also explaining the Qur'an's distinctive style, topic, and substance (Ali, 2012).

Abdullah Yusuf Ali's Holy Quran translation and commentary, written between 1934 and 1937, is possibly one of the most competent and accurate English translations of the Quran's inclusive language in the twentieth century. Yusuf Ali's translation tries to convey the Quran's universal message by appealing to human reason, highlighting the ethical and moral components of the Quran while also leveraging his profound linguistic and historical insights, but without delving into any of Islam's core belief structures (Lei, 2020). The work is invaluable for anyone sincerely interested in learning the Quran and gaining an analytical comprehension of its meaning, with over 6,000 commentary notes and thirteen appendices assisting the translation (Lei, 2020).

To assume, a parable can be drawn directly from the Noble Qur'an in specific words, or whether, in general, any simple story used to illustrate a moral or spiritual lesson based on those verses in the Noble Qur'an, such as the story of prophets, can be included in general terms as a parable. When Allah seeks to clarify an essential point, he utilizes a powerful speech figure, a narrative, or a metaphor that lingers in the mind and allows us to grasp the lesson and set it firmly in our hearts. For the speaker, metaphorical language has a specific meaning and function at certain times and in certain settings of discourse. One of them is to use language to create beauty. Speakers or sources, levels of metaphors, and environmental conditions are all variables underlying the senses (Marsin, Iskandar, \& Attas, 2019).

The parable of the noble Qur'an is examined in this study utilizing a stylistic approach, as language style is acknowledged as a component of linguistic studies. The employment of words in a language to communicate messages to readers or listeners is a factor to consider. Applied linguistic studies include linguistic studies in a literary text (Cook, 2003). Literary Stylistics is the term used in linguistics to describe this. Literary stylistics, as a type of applied linguistics in literary texts, has grown in importance and influence (Cook, 2003). This emphasizes that stylistics encompasses all parts of language, including sounds, words, and sentences. Language style is inextricably linked to other characteristics and the overall structure of the language. As a result, it is clear that language style study or analysis is carried out within the framework of Structuralism-Semiotics. To put it another way, the language style is a system of meaningful signs.

A language style is defined as style in literature. The term "language style" refers to how an author uses language in an article or how he or she expresses anything that will be expressed (Abrrams, 1981). The semiotic function of literary language, namely language as 
a first-level semiotic system and literature as a second-level semiotic system, is related to literary language. Literary language, in particular, contains the following characteristics: emotive, connotative, stylistic (soul), and indeterminate expression. Emotional language has a wide range of ambiguity, such as homonyms or irrational categories; literary language is saturated with historical events, recollections, and associations. Literary language is conotative, which implies that it has many more meanings than just the ones it refers to (Wellek, Rene, \& Waren, 1989). Literary language is also expressed in a language style that is used to create certain effects, especially aesthetic effects (Pradopo, 1997).

Literary works, like human imaginative works, frequently employ language as an expression medium with a strong aesthetic purpose. Writers frequently employ literary language as a medium of expression for literary works to cause / bring up particular meaning effects in order to attain aesthetic benefits (Al-Ma'ruf, 2017). Language style is related to this in that it becomes a means or way to express thoughts, ideas, and the speaker's taste, and therefore becomes a mirror of the speaker's thinking style. Readers and listeners can use language style to collect messages, thoughts, and sentiments from speakers or writers. This is referred to by Leech and Short (1981) in (Semino, Elena, \& Culpeper, 2002) as a Mind Style, defined as the way the fictitious world is comprehended and imagined through the use of language in various settings for specific objectives (Semino, Elena, \& Culpeper, 2002). Literary works are sometimes known as the world in words and the world in imagination. A speaker or writer expresses everything in a literary work with words, with language, in an universe that is embodied, formed, offered, and abstracted in words, with language.

Metaphor, metonymy, antonomasia, and irony are examples of the first type of stylistic devices, which rely on the interaction of lexical and contextual meaning. Epithet, oxymoron, hyperbole, and meiosis, depending on various sorts of word sense, are the second types of stylistic techniques (Bahri, 2020). Meanwhile, the Stylistic analysis metaphor includes the idiosyncratic method in which the metaphor is used in a particular text by individual writers or, more broadly, by a college, generation, or similar social grouping of writers (Steen, 2016). Simile, synecdoche, metonymy, catachresis, and zeugma are among the metaphorical tropes that used to be part of the 'rhetoric' subject (Grey, 2015). Metaphors can also be classified as similes, personifications, anthropomorphisms, hyperboles, parables, fables, and analogies. Richards in (Bajwa, 2017), as defines in Rhetoric's Philosophy (1937) The tenor and the vehicle are two aspects of the metaphor. The tenor is the person or thing to whose qualities are assigned, whereas the vehicle is the thing from which attributes are borrowed (Bajwa, 2017). 
Metaphor is the representation or perception of meaning from two perspectives, one from one side and the other from the other. Metaphor implies two points: contrast and uncommon representation. First and foremost, a metaphorical code necessitates a focus or likeness comparison. Second, a metaphor refers to a novel manner of approaching code (Khoda, 2015). There are also five types of metaphors: i. Cognitive metaphor: an object's relationship to the outer world ii. A conceptual metaphor is one in which language and ideas are linked. iii. Root metaphor: a person's worldview impacts how they understand a situation in the real world. Non-linguistic metaphor: a relationship is formed between two nonlinguistic components. iv. Visual metaphor: the use of an image in conceptual formulation or interpretation (Bajwa, 2017). Moreover, we may also find many kinds of speech figures, such as metaphor, personification, irony, alliteration, onomatopoeia, and assonance, for example (Suparlan, Muliadi , \& Masyudin, 2019). In addition, according to (Suparlan, Muliadi , \& Masyudin, 2019) Cognitive metaphor, conceptual metaphor, root metaphor, and visual metaphor are the five types of metaphors available. We can also come across a variety of speech figures, such as metaphor, personification, irony, alliteration, onomatopoeia, and assonance, to name a few (Suparlan, Muliadi , \& Masyudin, 2019)

There are a few different types of metaphor, each serving a different purpose (Blum, 2020). I The most common metaphor compares two objects that are $Y$, as opposed to objects that employ the simple X construction. Shakespeare's statement "All the world's a stage" is a classic metaphor. (ii) Implied: An implied metaphor is a form of metaphor that connects two unrelated objects without mentioning one of them explicitly. "A mom shouted an alert at her youngster," for example. The suggested metaphor here compares a woman to a dog without expressly naming the dog. iii) Visual: A visual metaphor is similar to a visual image that implies an association. Visual representations are commonly utilized in advertisements, for example a car manufacturer showing their new sports car next to an image of a panther. The analogy is used to demonstrate that the wild animal is just as slick, swift, and cool as the car.iv) Extended: an extended metaphor is a type of metaphor that extends over a number of lines, paragraphs, or stanzas in prose or poetry (Blum, 2020).

To elaborate, the researchers develop two research questions based on the abovementioned theories: What types of metaphor are in parables from the noble Qur'an? And what kinds of metaphors are most common? As a result, the goals of this study are to look into the different types of metaphor in parables from the noble Qur'an, where a type of parable appears frequently. 


\section{B. Research Method}

This study uses a descriptive qualitative approach (Creswell \& Creswell, 2018; Huges, 2003; Mills \& Gay, 2018). The stylistic method adopted in this study was corpusbased. The research employed a corpus-linguistic approach in which the term or pattern under discussion was contextualized: (fine-grained) (Gries, 2015). Moreover, that in which the term or pattern in question is examined through a thorough examination of its meaning, which typically includes the examination of an element's concordance lines and their annotation for various linguistic and/or contextual characteristics; such data are analyzed using general statistical instruments, i.e. techniques similar to those used in psychology, ecology, and other fields; such data are analyzed using general statistical instruments, i.e. techniques similar to those used in psychology, ecology, and other fields; such data are analyzed (Gries, 2015). In addition, stylistic analysis was employed to clarify the metaphor meaning in context after the result of identification was analyzed. "Stylistics is the study of language and the language of literature in all its manifestations, and is one of the moderate approaches to literature," according to (Tariq, 2018), "Stylistics is the study of language and the language of literature in all its manifestation and is, one of the moderate approaches to literature".

The data source of this research are taken from Quranic Arabic Corpus (corpus.quran.com, 2020), an annotated linguistic resource for the Holy Quran. This page shows seven parallel translations in English. To compare the result, the researchers also use the corpus data of Quran.com (Qur'an.com, 2020). The English translation of the verses taken from (corpus.quran.com, 2020) and the commentary are from the Meaning of the Glorious Qur'an: Text, Translation \& Commentary by Abdullah Yusuf Ali (Ali, 2012). The data is in the form of English translation of the verses. The steps of data collection, as well as the documentation strategies that were used, were combined with the steps of data analysis. 1) Go to (Qur'an.com, 2020); 2) searching the key word of "parable"; 3) selecting the English translation of Yusuf Ali; 4) Compare to (corpus.quran.com, 2020); 5) Identify and categorize the parable based on the classification given by (Blum, 2020); 6) Explain the meaning from the researchers' perspective and from the commentary in Yusuf Ali (Ali, 2012). 


\section{Finding Research}

The research's data are some English translation verses of the noble Qur'an obtained from corpus data based on the following criteria: (corpus.quran.com, 2020). The Quranic Arabic Corpus, an annotated linguistic resource for the Holy Quran, provided the corpus data for this study. The scripts were based on Yusuf Ali's translation. The researchers also used the corpus data from (Qur'an.com, 2020) to compare the results.

There are found 53 verses of parable terms stated on the meaning of noble Qur'an in (Qur'an.com, 2020) and 38 verses of parable terms from Yusuf Ali (Ali, 2012). The term parable is identically has the same in meaning with metaphor (Bajwa, 2017). So, the different amount of this two corpus data refers to the larger sources used in (Qur'an.com, 2020). This research focused on the parable in Yusuf Ali (Ali, 2012). The data then classify into four types of metaphor namely: standard, implied, visual, and extended (Blum, 2020). The classification as presented in the following tabel:

Tabel 1. Metaphor Types of Parable from the Nobel Qur'an

\begin{tabular}{|c|c|c|c|c|}
\hline NO. & KINDS OF METAPHOR & QUANTITY & $\begin{array}{c}\text { NO. OF SURAH } \\
\text { \& VERSE }\end{array}$ & PERCENTAGE \\
\hline 1. & Standard & 23 & $\begin{array}{c}\text { [2:17-18], [2:19- } \\
20],[2: 261], \\
\text { [3:103], [9:109- } \\
110],[10: 24], \\
{[11: 24],[14: 18],} \\
{[14: 24-25],[14: 26} \\
],[16: 75],[16: 76], \\
{[16: 92],[18: 45-} \\
46],[24: 35-36], \\
{[24: 39],[24: 40],} \\
{[30: 28],[39: 29],} \\
{[57: 20],[67: 30],} \\
\text { [59:21], [48:29] }\end{array}$ & $61 \%$ \\
\hline 2. & Implied & 5 & $\begin{array}{c}{[2: 259],[13: 35]} \\
{[16: 112-113]} \\
{[47: 15],[57: 20]}\end{array}$ & $13 \%$ \\
\hline 3. & Visual & 7 & $\begin{array}{c}{[2: 171],[2: 264],} \\
{[7: 176],[22: 31],} \\
{[22: 73],[29: 41],} \\
{[62: 5]}\end{array}$ & $18 \%$ \\
\hline 4. & Extended & 3 & $\begin{array}{c}{[18: 32-44],[36: 13-} \\
32],[68: 17-33]\end{array}$ & $8 \%$ \\
\hline \multicolumn{2}{|c|}{ AMOUNT } & 38 & & $100 \%$ \\
\hline
\end{tabular}

Tabel 1 reveals that standard metaphor is found in 21 verses, or 61 percent of all metaphor. It is divided as five verses, or 13 percent, as implied metaphor, seven verses, or 
18 percent, as visual metaphor, and three verses, or $8 \%$, as extended metaphor. The following chart 1 can help you grasp it more vividly:

\section{Chart 1. Percentage of Metaphor Types from Parable}

\section{Metaphor Types of Parable in the Noble Qur'an}

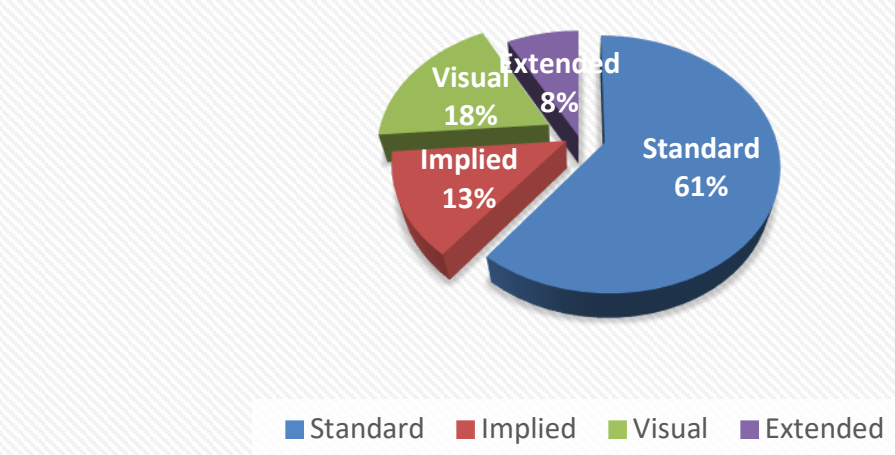

From the 38 metaphor identified, the researchers took 8 verses as the sample to be presented:

1. Standard. A typical metaphor compares two objects that are Y, as opposed to objects that have a basic X structure (Blum, 2020). (QS al-Mu'min [40]; 43)

a. Man who kindled a fire (QS. al-Baqarah [2]:17-18)

"Their similitude is that of a man who kindled a fire; when it lighted all around him, Allah took away their light and left them in utter darkness. So they could not see. Deaf, dumb, and blind, they will not return (to the path)" (corpus.quran.com, 2020).

Unbelievers believe they are doing the right thing [as symbolized by the fire that provides light], but they have just lost their senses because they have been diverted from worshiping the One True God-Allah.

b. Rain-Laden Cloud (QS. al-Baqarah [2]: 19-20).

"Or (another similitude) is that of a rain-laden cloud from the sky: In it are zones of darkness, and thunder and lightning: They press their fingers in their ears to keep out the stunning thunder-clap, the while they are in terror of death. But Allah is ever round the rejecters of Faith! The lightning all but snatches away their sight; every time the light (Helps) them, they walk therein, and when the darkness grows on them, they stand still. And if Allah willed, He could take away their faculty of hearing and seeing; for Allah hath power over all things" (corpus.quran.com, 2020). 
This parable implies that Allah has absolute authority [as symbolized by the rain-soaked cloud] and that unbelievers are terrified of dying [and hence of encountering Allah on the Last Day]. The unbelievers try to ignore reality, but Allah's wrath is still upon them. Despite the fact that Allah gave them the five senses with which they were born, they remain in the dark, unable to see the Truth.

2. Implied. An implied metaphor is a form of metaphor that compares two things that aren't the same without expressly mentioning one of them. "A mom shouted an alert at her youngster," for example. The suggested metaphor here compares a woman to a dog without expressly naming the dog (Blum, 2020)

c. Hamlet in ruins (QS. al-Baqarah [2]: 171)

"Or (take) the similitude of one who passed by a hamlet, all in ruins to its roofs. He said: "Oh! how shall Allah bring it (ever) to life, after (this) its death?" but Allah caused him to die for a hundred years, then raised him up (again). He said: "How long didst thou tarry (thus)?" He said: (Perhaps) a day or part of a day." He said: "Nay, thou hast tarried thus a hundred years; but look at thy food and thy drink; they show no signs of age; and look at thy donkey: And that We may make of thee a sign unto the people, Look further at the bones, how We bring them together and clothe them with flesh." When this was shown clearly to him, he said: "I know that Allah hath power over all things" (corpus.quran.com, 2020).

This verse implies that Allah has the power to regenerate man because he was created for the first time. Those who are revived from the dead on the Day of Judgment will have no remembrance of time or space [which are features peculiar to this ephemeral universe], meaning they won't be able to tell how long they've been dead or judge distance.

d. Grain of corn (QS. al-Baqarah [2]: 261)

"The parable of those who spend their substance in the way of Allah is that of a grain of corn: it groweth seven ears, and each ear Hath a hundred grains. Allah giveth manifold increase to whom He pleaseth: And Allah careth for all and He knoweth all things" (corpus.quran.com, 2020).

This verse signifies that Allah multiplies the reward of those who give to charity 700 times!

3. Visual. A visual metaphor is similar to a visual image that suggests an association. In advertising, visual imagery are frequently employed, such as a car company showing 
their new sports car next to a photo of a panther. The metaphor is used to show that the wild animal is just as slick, swift, and cool as the car (Blum, 2020)

e. Goat-Herd (QS. al-Baqarah [2]: 171)

"The parable of those who reject Faith is as if one were to shout Like a goatherd, to things that listen to nothing but calls and cries: Deaf, dumb, and blind, they are void of wisdom" (corpus.quran.com, 2020).

It means that, no matter how hard they try, unbelievers will be unable to find meaning and believe, because their capacity to reason has been rendered useless by their refusal to utilize their senses to believe.

f. Dog who lolls out its tongue (QS. al-A'raf [7]: 175-176)

"Relate to them the story of the man to whom We sent Our signs, but he passed them by: so Satan followed him up, and he went astray [7, 175]. If it had been Our will, We should have elevated him with Our signs; but he inclined to the earth, and followed his own vain desires. His similitude is that of a dog: if you attack him, he lolls out his tongue, or if you leave him alone, he (still) lolls out his tongue. That is the similitude of those who reject Our signs; So relate the story; perchance they may reflect" (corpus.quran.com, 2020).

The message is that those who get advise but ignore it are solely responsible for their actions.

4. Extended. An extended metaphor is a type of metaphor that extends over several lines, paragraphs, or stanzas in prose or poetry (Blum, 2020)

g. Undermined sand cliff (QS. at-Taubah [9]: 109-110)

"Which then is best? - he that layeth his foundation on piety to Allah and His good pleasure? - or he that layeth his foundation on an undermined sand-cliff ready to crumble to pieces? and it doth crumble to pieces with him, into the fire of Hell. And Allah guideth not people that do wrong. The foundation of those who so build is never free from suspicion and shakiness in their hearts, until their hearts are cut to pieces. And Allah is All-Knowing, Wise" (corpus.quran.com, 2020).

Meaning, disbelief is based on a very shaky foundation: the unbeliever is never confident of his acts or what will happen to him in the future, and he lives in continual fear of death. Those who believe, on the other hand, are steadfast in their belief that they will be rewarded by God for their good works and that God would be pleased with their circumstances. 
h. Companion of the city (QS. Yasin [36]: 13-32)

"Set forth to them, by way of a parable, the (story of) the Companions of the City. Behold!, there came messengers to it. When We (first) sent to them two messengers, they rejected them: But We strengthened them with a third: they said, "Truly, we have been sent on a mission to you." The (people) said: "Ye are only men like ourselves; and (Allah) Most Gracious sends no sort of revelation: ye do nothing but lie." They said: "Our Lord doth know that we have been sent on a mission to you: "And our duty is only to proclaim the clear Message." The (people) said: "for us, we augur an evil omen from you: if ye desist not, we will certainly stone you. And a grievous punishment indeed will be inflicted on you by us." They said: "Your evil omens are with yourselves: (deem ye this an evil omen). If ye are admonished? Nay, but ye are a people transgressing all bounds!" Then there came running, from the farthest part of the City, a man, saying, "O my people! Obey the messengers: "Obey those who ask no reward of you (for themselves), and who have themselves received Guidance. "It would not be reasonable in me if I did not serve Him Who created me, and to Whom ye shall (all) be brought back. "Shall I take (other) gods besides Him? If ((Allah)) Most Gracious should intend some adversity for me, of no use whatever will be their intercession for me, nor can they deliver me. "I would indeed, if I were to do so, be in manifest Error. "For me, I have faith in the Lord of you (all): listen, then, to me!" It was said: "Enter thou the Garden." He said: "Ah me! Would that my People knew (what I know)!- "For that my Lord has granted me Forgiveness and has enrolled me among those held in honour!" And We sent not down against his People, after him, any hosts from heaven, nor was it needful for Us so to do. It was no more than a single mighty Blast, and behold! they were (like ashes) quenched and silent. Ah! Alas for (My) Servants! There comes not a messenger to them but they mock him! See they not how many generations before them we destroyed? Not to them will they return: But each one of them all - will be brought before Us (for judgment). A Sign for them is the earth that is dead: We do give it life, and produce grain therefrom, of which ye do eat" (corpus.quran.com, 2020).

This passage means that Allah's messengers were dispatched to preach Islam in a city, but the residents threatened to stone them and punish them because they were bad. "You're the ones who are wicked - how can you call counsel 'evil,'"' the messengers said. You've gone beyond the point of no return in terms of evil?" One believing citizen from the outermost reaches of the city rushed forward and persuaded his fellow people to follow the messengers, stating the following: I Obey the messengers since 
they are not seeking money or any other form of compensation from you. ii] Allah's messengers have received guidance from Him and are disseminating it; iii] worship Allah since He is the only one who created you iv) You will be judged by Allah v] Why should I worship idols, statues that cannot defend me, either by battling Allah or interceding on my behalf, if Allah decides to punish me vi] If I were an idolator, I would be on the wrong path. This man was forgiven by Allah, and he was allowed to join Paradise. He still cared about his neighbors and prayed that they could find some sort of guidance. There were no more messengers dispatched to that location by Allah. A major volcanic eruption occurred, and the population were engulfed in ash. Allah is grieved by those who deserved to be punished for mocking messengers. This isn't the first time something like this has happened.

All metaphors teach us valuable lessons that we should consider. Anyone who takes the direction offered in the Holy Quran to heart will become a believer, even if he or she is not currently a believer. Those who perish in Hell cannot blame their fate on Heaven. They were told to believe in the truth and then execute justice, but they did not think about or perform good deeds. They followed their own 'self' ['nafs'] desires. They disobeyed Allah's instructions. The parables in the Holy Quran are part of Allah's guidance! So, obey the teaching of the Parables until it is too late.

\section{Conclusion}

This study looks at four different types of metaphors utilizing a stylistic corpus-based methodology. There are four types of metaphor: standard, implied, visual, and extended. Standard metaphor is found in 21 verses, accounting for $61 \%$ of all metaphor. It is divided as five verses, or 13 percent, as implied metaphor, seven verses, or 18 percent, as visual metaphor, and three verses, or $8 \%$, as extended metaphor. The most common type of metaphor is standard metaphor. There are 21 verses in standard metaphor, accounting for $61 \%$ of the total of 38 verses.

All metaphors provide valuable lessons for humans to consider. If a person takes the instruction presented in the Holy Quran to heart, he or she will become a believer if they are not already believers. Such offenders cannot blame Heaven for their deaths in Hell. They were told to believe in the truth and then practice justice, but they did not consider or perform good deeds. Their own'selves' ['nafs'] preferences were carried out. They refused to follow Allah's instructions. As a result, it is actually recommended to study, research, and select parables from the noble Qur'an as teaching materials because they are ideal for teaching and 
learning activities. Because different types of metaphor allude to distinct study goals, the varieties of metaphor in parable can be examined from many perspectives.

\section{E. Bibliography}

Abrrams, M. (1981). A Glossary of Literary Terms. Holt, Rinehart and Winston.

Al Hilali, M. M., \& Khan, M. M. (1996). Translation of the Meanings of The Noble Qur'ar In The English Language. Madinah: King Fahd Complex for the Printing of the Holy Qur'an.

Ali, A. Y. (2012). The Meaning of the Glorious Qur'an Text, Translation \& Commentry by: Abdullah Yusuf Ali. Retrieved from Islamic Buletin.org: https://www.pdfdrive.com/english-translation-of-the-noble-quran-by-yusuf-alie46652270.html

Al-Ma'ruf. (2017). Pengkajian Sastera Teori dan Aplikasi. CV. Jiwa Amarta.

Aulia, R. N. (2011). Menakar Kembali Pemikiran Feminisme Amina Wadud. Jurnal Studi Al-Qur'an , 7(1), 44 - 62

Bahri, S. (2020). The Different Types of Words Meaning in Minangkabau. Budapest nternational Research and Critics in Linguistics and Education (BirLE) Journal Volume 3, No 2 e-ISSN: 2655-1470 (Online), p-ISSN: 2655-2647 (Print) www.bircu-journal.com/index.php/birle, 695-705.

Bajwa, Z. A. (2017). Conceptual Metaphor Theory and Emotion Stylistics. An Analysis of Urdu Poems. Research Gate https://www.researchgate.net/publication/329374543, $1-16$.

Blum, J. (2020, October 2). What is a Metaphor Definition and Examples of Metaphor in Literature. Retrieved from Master Class: https://www.masterclass.com/articles/what-is-a-metaphor\#what-is-a-metaphor

Cook, G. (2003). Applied Linguistics. UK: Oxford University Press.

corpus.quran.com. (2020, October 26). Retrieved from corpus.quran.com: http://corpus.quran.com/translation.jsp?chapter $=47 \&$ verse $=15$

Creswell, J. W., \& Creswell, D. J. (2018). Reserach Design - Qualitative, Quantitative, aand Mixed Methods Approach (Fifth). Sage Publication, Inc.

Djamdjuri, D. S. (2014). The Ability of the Fourth Semester Students in Identifying the Adjectives and Adjectival Phrases from English Translation of Surah Al-Mulk. 
English Journal Vol. 15, No. 2 ISSN 1858-3490 http://ejournal.uikabogor.ac.id/index.php/ENGLISH/article/view/258/255, 30.

Djamdjuri, D. S. (2016). The Effectiveness of Character Education in English Language Teaching Through the Islamic Teaching Materials. Bogor: Pascasarjana Universitas Ibn Khaldun.

Djamdjuri, D. S. (2020). Students' Interest on the Use of Islamic Teaching Materials in English Language Teaching. Proceedings of the 1st International Conference on Recent Innovations (ICRI 2018) (pp. 2093-2100). Portugal: SCITEPRESS Science and Technology Publications, Lda.

Effendi, M. R. ., Khoerunnisa, I., \& Syaprudin, D. (2021). Improving the Ability to Read the Qur'an Through Qiro'ati Method. Muttaqien Publishing, 1(1), 319-330.

Effendi, M. R. (2021). Teologi Islam; Potret Sejarah dan Perkembangan Mazhab KAlam. Literasi Nusantara.

Grey, W. (2015). Metaphor and meaning. Research Gate https://www.researchgate.net/publication/43488033, 1-10.

Gries, S. T. (2015). Quantitative designs and statistical techniques. In D. Biber, \& R. Reppen, The Cambridge Handbook of English Corpus Linguistic (pp. 50-71). United Kingdom: Cambridge University Press.

Huges, C. (2003). Book Review: Disseminating Qualitative Research in Educational Settings. In Theory and Research in Education (Vol. 3, Issue 2). Open University Press. https://doi.org/10.1177/147787850500300209

Khoda, S. (2015). Pragmatics Analysis of The English Version of Education Method verses in The Book "Tafsir Pendidikan Islam". (Unpublished). . Bogor, Jabar: English Education Program UIKA.

Lei, S. (2020). The Meaning of the Holy Quran, Abdullah Yusuf Ali. Retrieved from Academia.edu: https://www.academia.edu/41513103/The_Meaning_of_the_Holy_Quran_Abdullah _Yusuf_Ali

Marsin, M., Iskandar, I., \& Attas, S. G. (2019). Metafora Cinta dalam Novel Balada Cinta Majenun Karya Geidurrahman El-Mishry. Jurnal KIBASP (Kajian Bahasa, Sastra Dan Pengajaran), 3(1), https://doi.org/https://doi.org/10.31539/kibasp.v3i1.913, 44-59.

Mills, G. E., \& Gay, L. R. (2018). Educational Research Competencies for analysis and application. In Educational Research (Twelfth). Pearson. 


\section{Morteza, A. (2016). STUDY OF MENTAL IMAGERY IN THE PARABLE OF THE} QURAN. The Turkish Online Journal of Design, Art and Communication DOI NO: 10.7456/1060NVSE/086, 2083-2811.

Muttaqien, A., Hadiyanto, A., \& Mardhiah, I. (2016). Pengarusutamaan Islam Nusantara Melalui PAI dalam Perspektif Dosen PAI UNJ. Jurnal Studi Al-Qur'an , 12(1), 1 21

Pradopo, R. D. (1997). Ragam Bahasa Sastera. Humaniora, 4(1).

Qur'an.com. (2020, October 26). Retrieved from Qur'an.com: https://quran.com/

Semino, Elena, \& Culpeper, J. (2002). Cognitive Stylistics. John Benjamins Publishing.

Siregar, K. I. (2021). Hermeneutika Hadis tentang "Hidupkan Saya Bersama Orang Miskin”(Analisis Kualitas dan Sharh Hadis). Hayula: Indonesian Journal of Multidisciplinary Islamic Studies, 5(1), 111-128.

Steen, G. (2016). Metaphor and Style. In P. Stockwell, \& S. Whiteley, The Cambridge Book of Stylistic (pp. 316-328). UK: Camridge University Press.

Suparlan, Muliadi , M., \& Masyudin. (2019). Stylistic Analysis of Edgar Allan Poe's "The Bells”. Vol. 1, No. 4, August 2019. http://ojs.unimal.ac.id/index.php/ijevs. DOI: https://doi.org/10.29103/ijevs.v1i4.1605. International Journal for Educational and Vocational Studies, 273-281.

Tariq, M. (2018). Tariq, M. (2018). Style, stylistics and stylistic analysis : A re-evaluation of the modern-day rhetorics of literary discourse. 46-50.

Wellek, Rene, \& Waren, A. (1989). Teori Kesusastraan (terjemahan). Jakarta: Gramedia. 